\title{
Household Food Insecurity, Level of Nutritional Adequacy, and Nutritional Status of Toddlers in the Coastal Area of Central Tapanuli Regency
}

\author{
Herta Masthalina $^{1 *}$, Heru Santosa ${ }^{2}$, Etti Sudaryati ${ }^{3}$, Fikarwin Zuskar ${ }^{4}$ \\ ${ }^{1}$ Public Health Doctoral Program, Faculty of Public Health Universitas Sumatera Utara, Medan, Indonesia; ${ }^{2}$ Department of \\ Biostatistics, Faculty of Public Health Universitas Sumatera Utara, Medan, Indonesia; ${ }^{3}$ Department of Nutrition, Faculty of \\ Public Health Universitas Sumatera Utara, Medan, Indonesia; ${ }^{4}$ Department of Anthropology, Faculty of Social and Political \\ Sciences Universitas Sumatera Utara, Medan, Indonesia
}

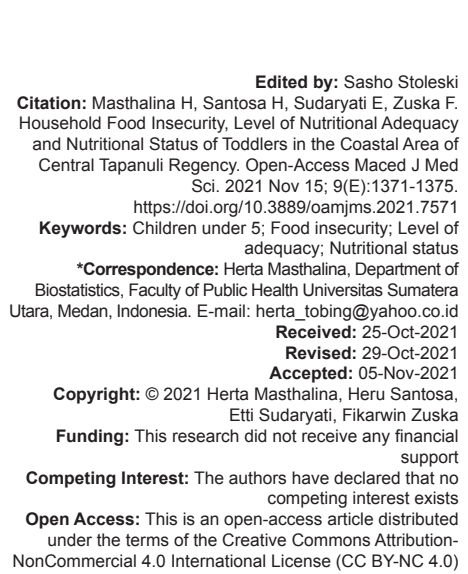

Introduction

Food security is one of the important aspects to achieve the Sustainable Development Goals. Food security at the family level will be realized if (1) the household can provide sufficient food, (2) nutritious and safe food can be easily accessed, and (3) its use is appropriate of the day so that it can meet the nutritional needs of the body to avoid from malnutrition. If these conditions are not achieved, a family will be said to be food insecure. In other words, food insecurity is the opposite of food security [1]

Food insecurity can affect the quality of health, starting from pregnancy until the child enters toddlerhood. Food insecurity that results in lack of food in children under 5 does not only affect their current health but also physical, mental, and social development [2]. The metaanalysis study conducted by Moradi et al. (2019) showed that food insecurity increased the risk of stunting (Odds ratio $[\mathrm{OR}]=1.1795 \%$ confidence interval $[\mathrm{Cl}]$ : 1.09-1.25) and underweight $(\mathrm{OR}=1.1795 \% \mathrm{Cl}$ : 1.01-1.36). The results of the analysis also showed that food insecurity increased the risk of stunted growth (OR $=1.2095 \% \mathrm{Cl}$ : 1.02-1.39) for children over 5 years. This association was significant only for the risk of stunting (OR = $1.1495 \% \mathrm{Cl}: 1.05-1.23)$ in children under 5 years [2]. Previously, the same thing was also conveyed by Larry, food insecurity that occurs in childhood affects cognitive, socioemotional levels, and ultimately interferes with academic achievement even if food insecurity is not resolved 3 years earlier [3]. Nutrition and food insecurity are interdependent components of public health and everyone's concern. Poor nutrition can lead to reduced immunity, stunted physical and mental development, and reduced productivity [4], [5].

Data from the North Sumatra Provincial Health Office in 2018, Central Tapanuli Regency, had stunting, malnutrition, and wasting nutritional status of $43.69 \%, 30.07 \%$, and $19.58 \%$, respectively. Almost half of the children under 5 in Central Tapanuli Regency experience stunting problems, while the 
problem of malnutrition shows that there is one-third of children under 5 in Central Tapanuli Regency currently experiencing malnutrition. The high nutritional problems in Central Tapanuli Regency are caused by inadequate food intake, sanitation, and hygiene as well as infectious diseases in children under 5 [6], [7].

The situation of food insecurity that occurs in several areas in Central Tapanuli Regency can be seen from household consumption and expenditure, the average amount of energy and protein consumption per capita per day is $2038.20 \mathrm{kcal}$ and $53.99 \mathrm{~g}$ of protein. This figure is still less than the nutritional adequacy rate recommended by the Ministry of Health of 2100 $\mathrm{kcal}$ and $57 \mathrm{~g}$ of protein. Likewise, spending on food at the family or household level is more than $65 \%$ of the total expenditure, which is $66.56 \%$, meaning that most of the household expenditure is spent on food needs [8]. According to the Food Security Agency, if the expenditure on food is above $65 \%$, it is declared as a household that is not food insecure; the higher the income of the community, the smaller the percentage of expenditure on food [9].

Coastal areas are regions that are remote from urban areas, making it more probable that health problems may develop owing to inadequate access and infrastructure, especially for coastal areas in the form of small islands that requires specific transportation [10]. The coastal communities of West Sorkam, Central Tapanuli Regency, are mostly (85\%) of the coastal Batak tribe, and their primary source of income is fishing, with hardly any variation in economic status between families. The purpose of this study was to determine the level of household food insecurity, nutritional adequacy, and nutritional status of children under 5 in the Central Tapanuli Regency's coastal area.

\section{Methods}

This research is part of research from a dissertation with the title positive deviance in food Insecure Families in Improving the Nutritional Status of Toddlers in the Coastal Area of Central Tapanuli Regency, with the design of this research being Participatory Action Research. The research was conducted by interviewing respondents (mothers of toddlers) and taking anthropometric measurements of 59 children under 5 purposively in the coastal area of Central Tapanuli Regency. The sample in this study was purposive. This research stage was an action diagnosis stage, which is a stage that analyzes family food insecurity and the factors that influence it. This stage also assessed the nutritional status of children under 5 (good/poor nutrition, stunting/ not stunting, and wasting/not wasting). Data collection was carried out in Pasar Sorkam Village, West Sorkam District, in Central Tapanuli Regency. This research has been declared ethically qualified with the number 403/ KEP/USU/2021 from the ethics committee of the Faculty of Medicine, University of Sumatera Utara. Primary data were obtained from interviews using a questionnaire while secondary data were obtained from the Health Office of Central Tapanuli Regency. Determination of household food security status using the Food insecurity level method: Using the Household Food Insecurity Access Scale (HFIAS). All questionnaires were translated into Indonesian and surveys were delivered in one-on-one interviews in the Indonesian language. HFIAS scores range from absolute food security (score $=0$ ) to very severe food insecurity (maximum score $=27$ ). There are four categories of food insecurity status, according to the HFIAS guidelines: "Food insecure (0-1)," "mild food insecurity (2-7)," "moderate food insecurity (8-14)," and "severe food insecurity (15-27)." Reliability analysis was conducted to test the internal consistency for the nine HFIAS questions. To facilitate data processing, the criteria for food insecurity were divided into two, namely, food security and food insecurity.

The nutritional status of children under 5 was measured using the index $\mathrm{BB} / \mathrm{U}$ (weight for age) and $\mathrm{PB} / \mathrm{U}, \mathrm{TB} / \mathrm{U}$ (body length or height for age). Data were collected by: Children under 5 were weighed and their height measured to determine nutritional status. The child's age in months was assessed using two sources, first from the mother's answer when interviewed, and second based on the date of birth listed on the health monitoring card/record at the neighborhood health centers or posyandu. If the months did not match, the posyandu registration was used as the main source.

The data were processed and analyzed using the Statistical Package for the Social Sciences program in the form of univariate and bivariate analysis. The presentation of data was in the form of a distribution table of respondent characteristics and cross-tabulation between household food insecurity status with the adequacy of nutritional intake of children under 5 and nutritional status of children under 5 . Household food security status, nutritional adequacy, and nutritional status of children under 5 are presented as categorical data. The analysis used the Chi-square statistical test to determine the significance of the relationship between the two variables with a value of $\alpha=0.05$

\section{Results}

The description of family characteristics includes the mother's last education, mother's occupation, family income, food expenditure, and household food security status in Pasar Sorkam village. Most of the household heads (78\%) are fishermen. The highest level of knowledge of mothers under 5 is in the less category (61\%) even though the level of 
education of mothers is at most included in the category of secondary education level (59.3\%). Most of the family income $(66.1 \%)$ is below the regional minimum wage in Central Tapanuli Regency. The distribution of family characteristics of children under 5 in this study is presented in Table 1.

Table 1: Characteristics of toddler families

\begin{tabular}{|c|c|c|}
\hline Variables & $\mathrm{n}$ & $\%$ \\
\hline \multicolumn{3}{|l|}{ Family head job } \\
\hline 1. Labor & 6 & 10.2 \\
\hline 2. Trader/entrepreneur & 7 & 11.9 \\
\hline 3. Fisherman & 46 & 78.0 \\
\hline \multicolumn{3}{|l|}{ Mother toddler's educational history } \\
\hline 1. Graduated from elementary school & 7 & 11.9 \\
\hline 2. Graduated from middle school & 11 & 18.6 \\
\hline 3. Graduated from high school & 35 & 59.3 \\
\hline 4. Graduated from college & 6 & 10.2 \\
\hline \multicolumn{3}{|l|}{ Mother toddler knowledge } \\
\hline 1. Adequate & 23 & 39.0 \\
\hline 2. Less adequate & 36 & 61.0 \\
\hline \multicolumn{3}{|l|}{ Family income } \\
\hline 1. Meet the regional minimum wage & 20 & 33.9 \\
\hline 2. Does not meet the regional minimum wage & 39 & 66.1 \\
\hline \multicolumn{3}{|l|}{ Expenditures on food } \\
\hline 1. Low & 49 & 83.1 \\
\hline 2. High & 10 & 16.9 \\
\hline \multicolumn{3}{|l|}{ Family food insecurity status } \\
\hline 1. Secure & 11 & 18.6 \\
\hline 2. Insecure & 48 & 81.4 \\
\hline \multicolumn{3}{|l|}{ Toddler nutritional status } \\
\hline \multicolumn{3}{|l|}{$\mathrm{Tb} / \mathrm{u}$ or $\mathrm{pb} / \mathrm{u}$} \\
\hline 1. Not stunting & 38 & 64.4 \\
\hline 2. Stunting & 21 & 35.6 \\
\hline \multicolumn{3}{|l|}{$\mathrm{BB} / \mathrm{u}$} \\
\hline 1. Good & 29 & 49.2 \\
\hline 2. Less & 30 & 50.8 \\
\hline \multicolumn{3}{|l|}{$\mathrm{BB} / \mathrm{Tb}$ or $\mathrm{BB} / \mathrm{PB}$} \\
\hline 1. No wasting & 53 & 89.8 \\
\hline 2. Wasting & 6 & 10.2 \\
\hline \multicolumn{3}{|l|}{ Nutritional problems } \\
\hline 1. No & 26 & 44.1 \\
\hline 2. Yes & 33 & 55.9 \\
\hline \multicolumn{3}{|l|}{ Nutritional adequacy level of toddlers } \\
\hline \multicolumn{3}{|l|}{ Energy } \\
\hline 1. Enough & 20 & 33.9 \\
\hline & 39 & 66.1 \\
\hline \multicolumn{3}{|l|}{ Protein } \\
\hline 1. Enough & 23 & 39 \\
\hline 2. Less & 36 & 61 \\
\hline
\end{tabular}

Table 2 shows that in families experiencing food insecurity, children under 5 tend to experience less energy intake $(79.1 \%)$ compared to families who are food insecure, most $(90.9 \%)$ have adequate intake. The relationship between family food insecurity status is related to the level of adequacy of energy intake of children under $5(p=0.000)$.

Table 2: Cross-tabulation of food insecurity status with energy adequacy level of toddler

\begin{tabular}{|c|c|c|c|c|c|c|c|c|}
\hline \multirow{3}{*}{ Food insecurity status } & \multicolumn{4}{|c|}{ Energy adequacy level } & \multirow{2}{*}{\multicolumn{2}{|c|}{ Total }} & \multirow[t]{3}{*}{$p$-value } & \multirow[t]{3}{*}{ OR } \\
\hline & \multicolumn{2}{|c|}{ Adequate } & \multicolumn{2}{|c|}{ Inadequate } & & & & \\
\hline & $\mathrm{n}$ & $\%$ & $\mathrm{n}$ & $\%$ & $\mathrm{n}$ & $\%$ & & \\
\hline Food secure & 10 & 90.9 & 1 & 9.1 & 11 & 100 & 0.000 & 38.0 \\
\hline Food insecure & 10 & 20.8 & 38 & 79.1 & 48 & 100 & & \\
\hline
\end{tabular}

OR: Odds ratio.

Table 3 shows that household experience food insecurity, children under 5 tend to experience less protein intake $(70.8 \%)$ compared to families who are food insecure, most of them (81.8) have adequate intake. The relationship between family food insecurity statuses is related to the level of protein intake of children under 5 years old $(p=0.002)$.

According to the cross-tabulation in Table 4, it is known that from families that are food secure, most of the children under 5 are well-nourished (81.8\%)
Table 3: Cross-tabulation of food insecurity status with protein adequacy level of toddlers

\begin{tabular}{|c|c|c|c|c|c|c|c|c|}
\hline \multirow[t]{3}{*}{ Food insecurity status } & \multicolumn{4}{|c|}{ Protein adequacy level } & \multirow{2}{*}{\multicolumn{2}{|c|}{ Total }} & \multirow[t]{3}{*}{$p$-value } & \multirow[t]{3}{*}{ OR } \\
\hline & \multicolumn{2}{|c|}{ Enough } & \multicolumn{2}{|c|}{ Not enough } & & & & \\
\hline & $\mathrm{n}$ & $\%$ & $\mathrm{n}$ & $\%$ & $\mathrm{n}$ & $\%$ & & \\
\hline Food secure & 9 & 81.8 & 2 & 18.2 & 11 & 100 & 0.002 & 10.929 \\
\hline Food insecure & 14 & 29.2 & 34 & 70.8 & 48 & 100 & & \\
\hline
\end{tabular}

and families who are not food insecure most of the children under 5 are undernourished (58.3\%). This shows that there is a tendency that children under 5 who are in a family condition that is not food insecure will experience anemia compared to those who are food insecure $(\mathrm{OR}=6.3)$, statistics shows that the relationship between food security status and nutritional status of children under 5 based on the BW/U index is significantly related $(p=0.039)$.

Table 4: Cross-tabulation of food insecurity status with nutritional status of toddlers based on $\mathrm{BB} / \mathrm{U}$

\begin{tabular}{|c|c|c|c|c|c|c|c|c|}
\hline \multirow[t]{3}{*}{ Food insecurity status } & \multicolumn{4}{|c|}{ Nutritional status $\mathrm{BB} / \mathrm{U}$} & \multirow{2}{*}{\multicolumn{2}{|c|}{ Total }} & \multirow[t]{3}{*}{$p$-value } & \multirow[t]{3}{*}{ OR } \\
\hline & \multicolumn{2}{|c|}{ Good } & \multicolumn{2}{|c|}{ Less } & & & & \\
\hline & $n$ & $\%$ & $n$ & $\%$ & $\mathrm{n}$ & $\%$ & & \\
\hline Food security & 9 & 81.8 & 2 & 18.2 & 11 & 100 & 0.039 & 6.300 \\
\hline Food insecurity & 20 & 41.7 & 28 & 58.3 & 48 & 100 & & \\
\hline
\end{tabular}

OR: Oral radio.

The results showed that food-insecure families had the nutritional status of children under 5 years old based on $\mathrm{TB} / \mathrm{U}$ or $\mathrm{PB} / \mathrm{U}$ who were stunting as much as $18.2 \%$, while in food-insecure families, the nutritional status of children under 5 who were not stunted was $39.6 \%$ (Table 5)

Table 5: Cross-tabulation of food insecurity status with nutritional status of toddlers based on TB/U or PB/U

\begin{tabular}{|c|c|c|c|c|c|c|c|c|}
\hline \multirow[t]{3}{*}{ Food insecurity status } & \multicolumn{4}{|c|}{$\begin{array}{l}\text { Nutritional status } \mathrm{tb} / \mathrm{u} \\
\text { or } \mathrm{pb} / \mathrm{u}\end{array}$} & \multirow{2}{*}{\multicolumn{2}{|c|}{ Total }} & \multirow[t]{3}{*}{$p$-value } & \multirow[t]{3}{*}{ OR } \\
\hline & \multicolumn{2}{|c|}{ Good } & \multicolumn{2}{|c|}{ Less } & & & & \\
\hline & $n$ & $\%$ & $\mathrm{n}$ & $\%$ & $\mathrm{n}$ & $\%$ & & \\
\hline Food security & 9 & 81.8 & 2 & 18.2 & 11 & 100 & 0.297 & 2.95 \\
\hline Food insecurity & 29 & 60.4 & 19 & 39.6 & 48 & 100 & & \\
\hline
\end{tabular}
Food insecurity

The results showed that the nutritional status of toddlers who were wasting was not found in resistant families, while in food-insecure families, the nutritional status of children under 5 who were wasting was $12.5 \%$ (Table 6).

Table 6: Cross-tabulation of food insecurity status with nutritional status of toddlers based on BB/TB or BB/PB

\begin{tabular}{|c|c|c|c|c|c|c|c|c|}
\hline \multirow[t]{3}{*}{$\begin{array}{l}\text { Food insecurity } \\
\text { status }\end{array}$} & \multicolumn{4}{|c|}{$\begin{array}{l}\text { Nutritional status BB/TB or } \\
\text { BB/PB }\end{array}$} & \multirow{2}{*}{\multicolumn{2}{|c|}{ Total }} & \multirow[t]{3}{*}{$p$-value } & \multirow[t]{3}{*}{ OR } \\
\hline & \multicolumn{2}{|c|}{ No wasting } & \multicolumn{2}{|c|}{ Wasting } & & & & \\
\hline & $\mathrm{n}$ & $\%$ & $n$ & $\%$ & $\mathrm{n}$ & $\%$ & & \\
\hline Food security & 11 & 100 & 0 & 0 & 11 & 100 & 0.581 & 1.143 \\
\hline Food insecurity & 42 & 87.5 & 6 & 12.5 & 48 & 100 & & \\
\hline
\end{tabular}

\section{Discussion}

The factors that influence childhood malnutrition are very diverse. UNICEF's conceptual framework on malnutrition identifies [11] inappropriate 
feeding practices as a direct cause of malnutrition in children under 5 . In the practice of feeding children under 5 , it was found that the intake of energy nutrients for children under 5 was $66.1 \%$ in the less category and $61 \%$ in the less category in protein intake. Lack of nutrient intake from the recommended adequacy for a long period can lead to growth disorders and even reduce energy reserves in the body so that there is a state of malnutrition or poor nutrition. This will impact physical growth, having a shorter body, experiencing mental development disorders, and stunted intelligence. Lack of protein is often found along with a lack of energy, which can lead to marasmus [12]. In addition to food from a physical point of view, children also need other things to achieve optimal growth and development, knowledge about nutrition and food, and parental attitudes (upbringing) in feeding. Mistakes in choosing food will have a terrible impact on children both now and in the future. When viewed from the results of the study, most $(61.0 \%)$ mothers of children under 5 had knowledge of nutrition and food in the poor category. Most of the questions that were asked of the respondents that were not known by the mother were about the provision of complementary foods to breast milk and the nutritional status of stunting in children.

At the household level, household food insecurity status, socioeconomic conditions, and knowledge of nutritious food are some of the main factors that influence children's nutritional status [11]. The results of the study got that the income of the interviewed families was below the UMR in Central Tapanuli Regency as much as $66.1 \%$. Children from middle-income families have increased dietary diversity and reduced rates of malnutrition. More affluent households often use additional income to purchase non-staple foods, increasing household food diversity. A recent analysis found income to be a significant determinant of household dietary diversity in Bangladesh [13].

Malnutrition is the leading cause of death during childhood, accounting for more than $33 \%$ of child deaths worldwide [14]. The insufficient quality of food given to children observed in this study can be explained by various descriptions of the nutritional status of children under 5 . The results showed that the nutritional status of children under 5 who were undernourished was $50.58 \%$, stunting was $35.6 \%$, and wasting was $10.2 \%$. The rate of malnutrition and stunting is very far from the national figure where malnutrition is $17.7 \%$ and stunting is $30.8 \%$, also, this figure is still above the target set by the World Health Organization which is $20 \%$ [15].

Based on the category of food insecurity level, households in the coastal area of Central Tapanuli Regency with food insecurity status were $81.4 \%$. The influence of food security on children's nutritional status can be influenced by other determinants such as maternal knowledge about nutrition and child health-care practices, maternal nutritional status, food allocation, and utilization practices in the household as well as access to health services and healthy environmental conditions [16].

Family food insecurity affects the energy and protein intake of children under 5 . Food-insecure families tend to have adequate levels of energy and protein intake at 90.9-81.8\%, respectively, while in foodinsecure families, the energy and protein adequacy levels are only 20.8-29.2\%. Family food insecurity in the long term can affect food consumption by reducing the quality and quantity of food so that it can cause a lack of nutrients needed by the body and harm the growth of toddlers [17].

The results of the analysis using the Chi-square test show that household food security has a significant relationship with the incidence of malnutrition in children under 5 ( $p=0.0039)$, this indicates that household food security is a significant risk factor for the incidence of malnutrition in children under 5 in the coastal area of Central Tapanuli with an OR value of 6.38 , meaning that households in food-insecure conditions are at 6.38 times greater risk of having children under 5 with malnutrition than households in food-insecure conditions. Households with food security classified as food insecure can have an impact on nutrition and health problems for household members, especially vulnerable groups including toddlers. Toddlers who are in food-insecure household conditions will have good access to food, both in quality and quantity, and this will have an impact on the fulfillment of the nutritional needs of toddlers so that optimal nutritional status is achieved. In contrast to under-fives who are malnourished who are not food safe have less access to food so that the portion of food is reduced to share with other family members. The higher prevalence of nutritional disorders in children living in food-insecure households may be due to inadequate food intake, limited consumption of various food groups with low nutritional content, and coping mechanisms during food shortages [18]. Similar findings are also found in the results of a study conducted by Engidaye et al. (2019) that household food insecurity was also identified as a factor associated with childhood anemia, which means that children from food-insecure households are at 2.34 times greater risk of developing anemia [19].

The status of household food insecurity is not related to the nutritional status of stunting (TB/U or $\mathrm{PB} / \mathrm{U})$ and wasting (BB/TB or $\mathrm{BB} / \mathrm{PB})$ of children under 5 . This is indicated by Chi-square statistical analysis ( $p>0.005)$, but cross-tabulation shows that in food-insecure families, more children experience stunting $(39.6 \%)$ than in food-insecure families $(18.2 \%)$. The results of research conducted by Shinsugi et al. (2015). The level of food insecurity was not significantly related to child stunting in the study, but households with severe food insecurity had children who were more likely to experience stunting because they had been given tea/porridge with milk within $24 \mathrm{~h}$. As a result, 
some children do not eat 3 times a day, making them more susceptible to stunting compared to children who are not given tea or porridge as food [20].

\section{Conclusion}

Food-insecure households in the coastal area of Pasar Sorkam Village, Central Tapanuli Regency are as much as $81.4 \%$ and food secure as much as $18.6 \%$. The prevalence of undernourished children is $50.8 \%$, stunting is $35.6 \%$, and wasting is $10.2 \%$. There is a significant relationship between household food security and the incidence of malnutrition in children under 5 with food-insecure household conditions having a 6.3 times greater risk of suffering from malnutrition compared to under 5 with food-insecure household conditions.

\section{References}

1. Food and Agriculture Organization. Moving Forward on Choosing A Standard Operational Indicator of Women's Dietary Diversity. Roma: Food and agriculture Organization of the United Nation; 2015.

2. Moradi S, Mirzababaei A, Mohammadi H, Moosavian SP, Arab A, Jannat $B$, et al. Food insecurity and the risk of undernutrition complications among children and adolescents: A systematic review and meta-analysis. Nutrition. 2019;62:52-60. https://doi. org/10.1016/j.nut.2018.11.029

\section{PMid:30852458}

3. Larry $\mathrm{H}$. Does food insecurity at home affect non-cognitive performance at school? A longitudinal analysis of elementary student classroom behavior. Econ Educ Rev. 2011;30(1):157-76.

4. World Bank. The World Bank: Promoting Opportunity, Growth and Prosperity. Vol. 2014. Washington, DC, United States: World Bank; 2014.

5. World Health Organization (WHO). Primary Health Care: Closing the Gap Between Public Health and Primary Care Through Integration. New York, Washington, DC: World Health Organization; 2018.

6. Dinas Kesehatan Provinsi Sumatera Utara. Laporan Tahunan Dinas Kesehatan Provinsi Sumatera Utara; 2018.

7. Dinas Kesehatan Provinsi Sumatera Utara. Laporan Tahunan Dinas Kesehatan Provinsi Sumatera Utara; 2019.

8. Dinas Ketahanan Pangan dan Peternakan. Peta Ketahanan dan Kerentanan Pangan (Food Security and Vulnerability Atlas) Provinsi Sumatera Utara Tahun 2020, Medan; 2020.

9. Badan Ketahanan Pangan. Indeks Ketahanan Pangan Indonesia 2019. Badan Ketahanan Pangan Kementrian Pertanian; 2019.
Available from: http://www.bkp.pertanian.go.id/storage/app/ media/bahan 2020/ikp 2019 final.pdf

10. Anwar A, Sultan M. The degree of health of the archipelagic community in the Derawan Islands sub-district, Berau Regency. Higiene. 2016;2(1):27-32.

11. Ali NB, Tahsina T, Hoque DM, Hasan MM, Iqbal A, Huda TM, et al. Association of food security and other socio-economic factors with dietary diversity and nutritional statuses of children aged 6-59 months in rural Bangladesh. PLoS One. 2019;14(8):e0221929. https://doi.org/10.1371/journal. pone. 0221929

PMid:31465509

12. Jun S, Zeh MJ, Eicher-Miller HA, Bailey RL. Children's dietary quality and micronutrient adequacy by food security in the household and among household children. Nutrients. 2019;11(5):965. https://doi.org/10.3390/nu11050965 PMid:31035584

13. Tegegne M, Sileshi S, Benti T, Teshome M, Woldie H. Factors associated with minimal meal frequency and dietary diversity practices among infants and young children in the predominantly agrarian society of Bale Zone, Southeast Ethiopia: A community based cross sectional study. Arch Public Health. 2017;75(1):1-11. https://doi.org/10.1186/s13690-017-0216-6 PMid:29158896

14. World Health Organization (WHO). Global Database on Child Growth and Malnutrtion. Geneva: World Health Organization; 2021.

15. Badan Penelitian dan Pengembangan Kesehatan. Riset Kesehatan Dasar (Riskesdas) 2018; 2018.

16. Motbainor A, Worku A, Kumie A. Stunting is associated with food diversity while wasting with food insecurity among underfive children in East and West Gojjam Zones of Amhara region, Ethiopia. PLoS One. 2015;10(8):e0133542. https://doi. org/10.1371/journal.pone. 0133542

PMid:26285047

17. Mutisya M, Kandala NB, Ngware MW, Kabiru CW. Household food (in)security and nutritional status of urban poor children aged 6 to 23 months in Kenya Global health. BMC Public Health. 2015;15(1):1-11.

18. Legason ID, Atiku A, Ssenyonga $R$, Olupot-Olupot $P$, Barugahare JB. Prevalence of anaemia and associated risk factors among children in North-Western Uganda: A cross sectional study. BMC Hematol. 2017;17(1):1-9.

19. Engidaye G, Melku M, Yalew A, Getaneh Z, Asrie F, Enawgaw B. Under nutrition, maternal anemia and household food insecurity are risk factors of anemia among preschool aged children in Menz Gera Midir district, Eastern Amhara, Ethiopia: A community based cross-sectional study. BMC Public Health. 2019;19(1):968. https://doi.org/10.1186/ s12889-019-7293-0

PMid:31324244

20. Shinsugi $C$, Matsumura M, Karama M, Tanaka J, Changoma M, Kaneko S. Factors associated with stunting among children according to the level of food insecurity in the household: A cross-sectional study in a rural community of Southeastern Kenya. BMC Public Health. 2015;15(1):441. https://doi. org/10.1186/s12889-015-1802-6

PMid:25924925 